\title{
Effectiveness of mandatory vessel speed limits for protecting North Atlantic right whales
}

\author{
David W. Laist ${ }^{1, *}$, Amy R. Knowlton ${ }^{2}$, Daniel Pendleton ${ }^{2}$ \\ ${ }^{1}$ Marine Mammal Commission, 4340 East-West Highway, Rm. 700, Bethesda, Maryland 20814, USA \\ ${ }^{2}$ New England Aquarium, 1 Central Wharf, Boston, Massachusetts 02110, USA
}

\begin{abstract}
To reduce right whale Eubalaena glacialis deaths caused by ship collisions along the US East Coast, a rule was implemented on 8 December 2008 requiring all vessels $\geq 65$ feet $(19.8 \mathrm{~m})$ to travel 10 knots $\left(18.5 \mathrm{~km} \mathrm{~h}^{-1}\right)$ or less in 10 seasonal management areas (SMAs). To evaluate the effectiveness of this rule, we plotted the locations of all right whale and humpback whale Megaptera novaeangliae carcasses attributed to ship-strikes since December 1990 in US waters to determine their proximity to SMAs. In the $18 \mathrm{yr}$ pre-rule period, 13 of $15(87 \%)$ right whales and 12 of $26(46 \%)$ humpback whales killed by ships were found inside later SMA boundaries or within $45 \mathrm{nmi}(83 \mathrm{~km})$ of their perimeters during later active dates. In the first $5 \mathrm{yr}$ after the rule became effective, no ship-struck right whales were found inside or within $45 \mathrm{nmi}$ of any active SMA. This was nearly twice as long as the longest pre-rule period without discovery of a ship-struck carcass in those areas during effective time periods. Based on the $18 \mathrm{yr}$ pre-rule period, bootstrap resampling analyses revealed that the probability of finding no ship-struck whales in or near SMAs during the first $5 \mathrm{yr}$ post-rule period would be a statistically significant reduction in such deaths $(\mathrm{p}=0.031)$. The results suggest the rule has been effective at reducing right whale deaths. We suggest enlarging SMAs to include additional parts of the right whale migratory corridor.
\end{abstract}

KEY WORDS: North Atlantic right whales - Humpback whales - Ship strikes · Conservation · Vessel speed limits

Resale or republication not permitted without written consent of the publisher

\section{INTRODUCTION}

The North Atlantic right whale Eubalaena glacialis was hunted nearly to extinction by $1000 \mathrm{yr}$ of whaling that ended in the early 1900s (Reeves et al. 2007). Now one of the world's most endangered large whales (Marine Mammal Commission 2008), the species currently occurs almost exclusively over the continental shelf off the eastern USA and Canada. As of late 2013, it was estimated to number about 500 whales (www.narwc.org/papers.php?mc=3). The principal threats to its survival-vessel collisions and entanglement in fishing gear (Knowlton \& Kraus 2001, Moore et al. 2004, Knowlton et al. 2012, van der Hoop et al. 2013) - are the main constraints to its recovery (Kraus et al. 2005, National Marine Fish- eries Service 2005). From 1990 through 2012, more than half of all dead right whales found stranded or floating at sea (39 of 73) were attributable to ship collisions $(n=23)$ or entanglement $(n=16)$ (Knowlton \& Kraus 2001, Moore et al. 2004, Marine Mammal Commission 2013). With no apparent progress in reducing entanglement deaths (Knowlton et al. 2012, van der Hoop et al. 2013), reducing vessel collisions has become even more important.

Several early studies indicated that reducing ship speed in key right whale habitats could reduce vesselrelated whale deaths. Knowlton et al. (1995) modeled hydrodynamic forces around ships traveling at different speeds and concluded that objects the size and density of a whale can be pulled towards hulls and propellers of large ships with a force that increases as 
speeds increase above 10 knots. Clyne (1999) also simulated risks of collisions with vessels traveling at various speeds and found that collisions with the bow were more likely when speeds increased above 10 knots. Laist et al. (2001) examined accounts of accidental collisions with whales by vessels travelling at known speeds and concluded that lethal collisions increase sharply between speeds of 10 to 14 knots (18.5 to $15.9 \mathrm{~km} \mathrm{~h}^{-1}$ ) and were rare at speeds below 10 knots. Based on those findings the seasonal distribution of right whales, the location of ship-struck carcasses, and input from the shipping industry, Russell et al. (2001) recommended seasonal management areas with 10 knot speed limits off major ports and in key habitats along the eastern US coast. Assuming whale deaths due to ships are strictly a function of impact force and vessel hydrodynamics, Vanderlaan \& Taggart (2007) concluded that the greatest rate of change in the probability of lethal collisions was between vessel speeds of 8.6 to 15 knots (15.9 to $27.8 \mathrm{~km} \mathrm{~h}^{-1}$ ) and that the probability of death declined by $50 \%$ at speeds of $<11.8$ knots $\left(21.9 \mathrm{~km} \mathrm{~h}^{-1}\right)$.

Based largely on those findings and their own analyses, the National Marine Fisheries Service (NMFS) adopted a rule to limit vessel speeds in key US right whale habitats as part of its 'right whale ship-strike reduction strategy' (NMFS 2008a). The rule became effective on 8 December 2008 for a 5 yr period (i.e. until 8 December 2013). Although intended to protect right whales, the measure was also expected to provide some protection to humpback whales Megaptera novaeangliae and other large whales whose ranges overlap with those of right whales (NMFS $2008 \mathrm{~b})$. The rule requires all vessels 65 feet $(19.8 \mathrm{~m})$ or longer (also herein referred to as 'ships') to use speeds of 10 knots or less when transiting 10 Seasonal Management Areas (SMAs) along the US East Coast during periods of peak right whale occurrence (Fig. 1). The 10 SMAs comprise 6 that extend 20 nautical miles $(\mathrm{nmi} ; 3 \mathrm{~km})$ from shore, off major ports along the species' coastal migratory corridor between southern New England and Georgia (effective 1 November to 30 April); 3 in feeding areas off Massachusetts (i.e. Cape Cod Bay, effective 1 January to 15 May; the Great South Channel, effective 1 April to 31 July; and an area immediately east and north of Cape Cod, effective 1 March to 30 April); and 1 in the core of the species' calving grounds off the southeastern US coast of Georgia and Florida (effective 15 November to 15 April).

In addition to SMAs, the NMFS ship-strike reduction strategy included new vessel routing measures for the port of Boston in Massachusetts and 3 ports in the southeastern US right whale calving grounds, and established 2 other types of management areas: Dynamic Management Areas (DMAs) and a seasonal 'Area To Be Avoided' (ATBA). DMAs are temporary $15 \mathrm{~d}$ management areas established on short notice to protect aggregations of 3 or more right whales found at unpredictable locations outside of active SMAs. When DMA boundaries are announced through customary maritime communication media (e.g. voice radio and local notices to mariners) ships are asked, but not required, to limit speeds to 10 knots or to steer clear of those areas. ATBAs, established under the authority of coastal nations after approval of the International Maritime Organization, are areas where ship operators are asked, but not required, to avoid transits. Such an area off Nova Scotia, Canada, has been shown to be effective at reducing the risk of lethal vessel strikes in right whale habitats (Vanderlaan et al. 2008). The ATBA for right whale protection lies principally within the boundary of the Great South Channel SMA, east of the shipping lanes that run along that SMA's western edge (Fig. 1). The new routing measures: (1) narrowed and shifted the

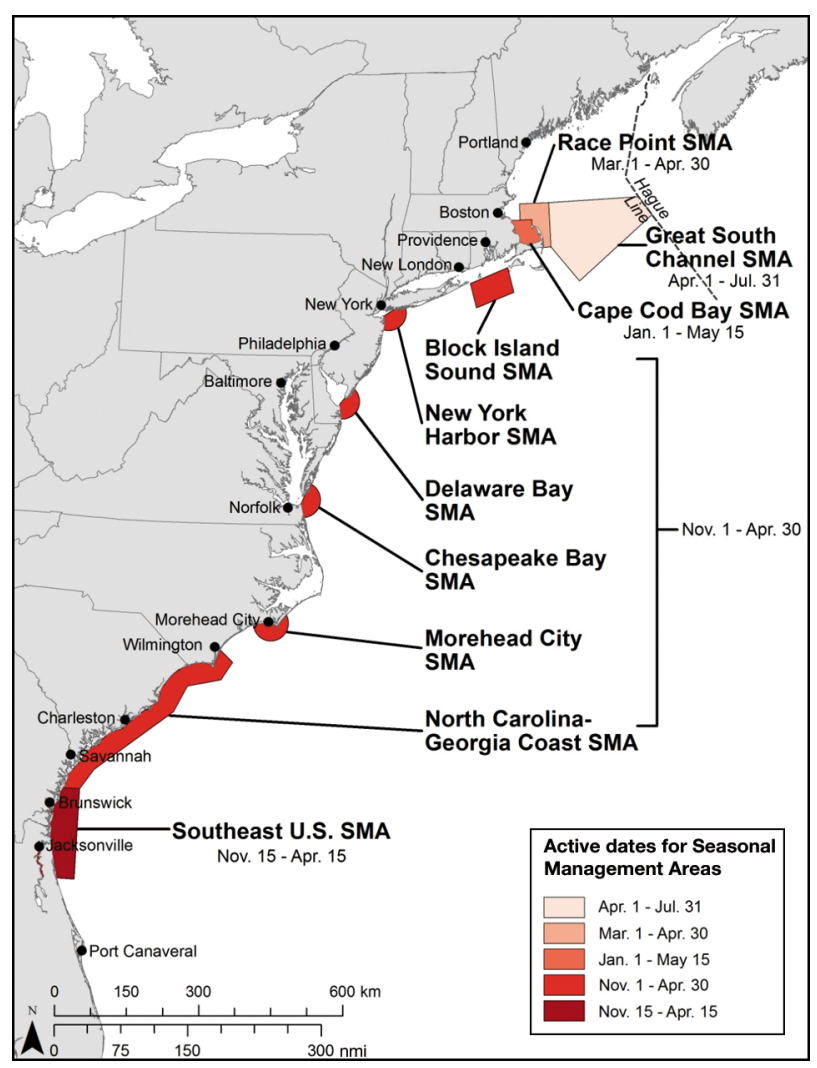

Fig. 1. Eubalaena glacialis. Locations and effective dates of Seasonal Management Areas (SMAs) requiring 10 knot ship speed limits after 8 December 2008 to protect North Atlantic right whales 
east-west leg of track of vessel traffic separation lanes leading into Boston Harbor to reduce overlap with right whale habitat in Cape Cod Bay (Silber et al. 2012a) and (2) recommended routes through Cape Cod Bay and off the ports of Jacksonville, Fernandina, and Brunswick to minimize transit distances through areas used least intensively by right whales (Lagueux et al. 2011).

Initially proposed in June 2006 (NMFS 2006), the rule finally adopted in 2008 was subject to a protracted review by high-level officials in the US government. Concerned about its economic impacts and skeptical of the measure's effectiveness, several changes were imposed on the action preferred by the NMFS. In part, the width of SMAs along the species' migratory corridor was reduced from 30 to $20 \mathrm{nmi}$ (55 to $37 \mathrm{~km}$ ), and a sunset provision was added requiring the rule to expire $5 \mathrm{yr}$ after its effective date (i.e. 8 December 2013). During the $5 \mathrm{yr}$ period the NMFS was to evaluate effectiveness of the speed requirement for reducing whale deaths and decide whether to extend, modify, or allow it to lapse. Another required change was making the 10 knot speed limit in DMAs voluntary instead of mandatory. On 9 December 2013, the rule was extended indefinitely subject to further review to determine if dredged channels through SMAs should be exempted from its provisions as requested by petition (NMFS 2013).

After the 2008 rule was adopted, the NMFS developed a plan to evaluate its effectiveness (Silber \& Bettridge 2009). Based on the first 3 yr of post-rule experience, the NMFS examined vessel compliance rates and economic impacts using data from an Automatic Identification System for ships (Silber \& Bettridge 2012) and evaluated its biological effectiveness based on intervals between all documented collisions with large whales along the east coast $2 \mathrm{yr}$ before the rules went into effect versus $2 \mathrm{yr}$ afterwards (Pace 2011). From those analyses, the NMFS concluded that biological data were not yet sufficient to reach statistically meaningful conclusions, but that "...there may be 'a meager amount of evidence in support of a reduction in ship-strike deaths and serious injuries of large whales' " (Silber \& Bettridge 2012, p. iv).

Several other studies have investigated compliance with the new speed restrictions in both SMAs (Silber \& Bettridge 2010, Lagueux et al. 2011, Mueller et al. 2011, Wiley et al. 2011) and DMAs (Asaro 2012, Silber et al. 2012b). Initial compliance in SMAs was poor, but improved after warnings began to be issued in late 2009 and improved further after notices of vio- lations with speed limits were issued in late 2010 (Silber \& Bettridge 2012). Most ships, however, reduced their speed to varying degrees, although not necessarily to 10 knots. Compliance in DMAs was very poor. This result was similar to a voluntary request asking vessels to travel at 10 knots off Southern California to protect blue whales, which resulted in almost no change in vessel speeds (McKenna et al. 2012). Still other studies have recently provided further evidence that collision risks increase as vessel speeds increase above 10 knots due to hydrodynamic effects (Silber et al. 2010), and whale deaths are correlated with vessels traveling at increasing speeds (Conn \& Silber 2013).

The reason why slow speeds are thought to reduce lethal collisions is subject to debate. Some suggest it is due solely to reduced impact and hydrodynamic forces (Vanderlaan \& Taggart 2007, Vanderlaan et al. 2009, Silber et al. 2010); others suggest it provides added time for whales to avoid oncoming ships (Laist et al. 2001, Gende et al. 2011). Regardless of the mechanism and its intuitive rationale for reducing speed to reduce collision risks, the effectiveness of speed requirements remains poorly documented and is still subject to doubt by some. To further explore whether speed restrictions have been effective at reducing lethal whale collisions, we examined information on known and possible ship-strike deaths of right and humpback whales found in and near SMAs before and after the NMFS implemented its rules limiting ship speeds along the US East Coast.

Specifically, we examined the locations and discovery dates of all right whale and humpback whale carcasses attributed to ship strikes or unknown causes to determine their proximity to SMA boundaries and their occurrence relative to SMA effective dates before and after the rule went into effect on 8 December 2008. We did not include fin whales because, unlike right whales and humpback whales, they can be carried 1000s of kilometers into ports on the bows of ships making it unclear where they were struck (Laist et al. 2001). We also did not consider other large whales (i.e. sperm, blue, sei, or minke whales), because they occur infrequently in areas where SMAs have been designated and because lethal collisions with those species along the US East Coast have been rare over the past 25 yr (Laist et al. 2001). We hypothesized that the average annual tally of right whale carcasses, and possibly also humpback whale carcasses, attributable or possibly attributable to ships discovered in or near SMA boundaries during SMA time frames would be lower after the shipstrike reduction rule went into effect. 


\section{MATERIALS AND METHODS}

We searched the National Marine Mammal Stranding Database maintained by the NMFS for records of all known right whale and humpback whale deaths attributed to ship strikes along the eastern US and Canadian coasts after 8 December 1990. For right whales, we also examined the Right Whale Photoidentification Catalogue maintained by the New England Aquarium for such deaths. Because the NMFS ship-strike reduction strategy is focused on US waters, our analyses of SMA effectiveness used only records of dead whales found within the US Exclusive Economic Zone. We sought records from Canada (i.e. waters north and east of the Hague Line that serves as the boundary between the US and Canadian Exclusive Economic Zones; Fig. 1), the only other area where North Atlantic right whales are known to have been killed by ships, to indicate what proportion of the ship-collision problem occurs in US waters. For right whales, our study period extended through 8 December 2013, the latest date for which records were available from the Right Whale Photo-identification Catalogue. Because of delays in entering stranding data into the national database, analyses of humpback whales extended only through 8 July 2011.

We also searched for records of all right whale deaths after 8 December 1990 that were attributed to unknown causes, because some of those whales may have been killed by ship strikes (e.g. some whales were documented floating offshore, but were not examined closely). We selected 8 December 1990 as the start of our study period because: (1) that date generally corresponds with the time when East Coast carcass recovery efforts for right whales were expanded and necropsy teams began flensing carcasses to the bone to look for internal ship-collision injuries not always apparent externally, and (2) it was statistically convenient to use the same day and month as the 8 December 2008 effective date for the NMFS rule. Data recorded for each dead whale in the national stranding database include the date, latitude and longitude, and general description of where the carcass was first seen; the cause of death, if it can be determined; the whale's decomposition state; and a summary of necropsy results (if conducted) or other findings explaining the assigned cause of death. When those data for right whales were missing, supplemental information was obtained when available from the Right Whale Photo-identification Catalogue.

Carcass locations were mapped using ArcGIS Version 10.0. SMA boundaries were added using coor- dinates available from the NMFS. Separate maps showing carcass discovery locations before and after the rule went into effect on 8 December 2008 were prepared for right whales killed by ships and for right whales that died of unknown causes that might have involved ship collisions. To identify carcasses of whales possibly killed by ships, we narrowed the list of carcasses attributed to unknown causes by eliminating those that were thoroughly necropsied and had no signs of ship-collision injuries. We also prepared a map for humpback whales, but only for deaths attributed to ship strikes; 275 humpback whale carcasses attributed to unknown causes were not plotted. Much less effort is made to retrieve and necropsy dead humpback whales than right whales; thus, unlike the situation for right whales, almost no records of humpback whales could be ruled out as possibly being collision related. Because of the large number of humpback whale carcasses attributed to unknown causes and the inability to exclude any that were clearly not caused by ship collisions, we concluded that for this species it would not be possible to distinguish meaningful trends relative to ship collisions and implementation of SMAs from such carcasses.

From plotted locations we identified all right whale carcasses attributed to ship strikes and to unknown causes potentially involving ship strikes found inside SMA boundaries during effective time frames before and after the ship-strike reduction rule went into effect. For all other right whale carcasses in US waters, we calculated their distance to the nearest SMA boundary. To account for carcasses that may have drifted outside SMA boundaries after whales were struck and before they were found dead, we considered any carcasses inside SMAs or within 45 nmi $(74 \mathrm{~km})$ of SMA boundaries during their active time frames (hereafter referred to as 'in or near active SMAs') to be potential victims of collisions inside SMA boundaries. We did the same for humpback whale carcasses, but only for those attributed to ship strikes. We then calculated the average annual number of ship-struck carcasses found in or near active SMAs for each species during the $18 \mathrm{yr}$ pre-rule period and for post-rule periods of $5.0 \mathrm{yr}(1826 \mathrm{~d})$ for right whales and $2.5 \mathrm{yr}(942 \mathrm{~d}$ ) for humpback whales (i.e. the latest dates for which data were available).

The drift distance of $45 \mathrm{nmi}$ was based on estimates of carcass degradation and drift rates. Almost all right whale deaths attributed to ship collisions in this study were found moderately decomposed (Code 3) or fresher according to the 5 category ranking system (with Code 5 representing the most degraded) used 
to describe carcass degradation states (Geraci \& Lounsbury 2005). We estimated it would take a maximum of $6 \mathrm{~d}$ for a right whale carcass to become moderately decomposed. This was based on a right whale named Staccato (Catalogue No. 1014) that was photographed alive and uninjured on 15 April 1999 and next seen 5 d later floating dead off Cape Cod, Massachusetts, after being struck by a ship. Its carcass was towed ashore the day it was sighted and it was necropsied the following day (i.e. 21 April), at which time it was recorded as being moderately decomposed (i.e. Code 3). Although carcass degradation can proceed at different rates depending on temperature, because right whales along the US East Coast almost always occur in cool water similar to temperatures in Cape Cod Bay in April, we considered the April 1999 case to be the best available estimate of the time needed for a right whale to degrade to a Code 3 condition.

Average carcass drift rate was estimated from the distances of movements reported for 5 right whale carcasses seen drifting in US waters and later resighted at another location. These carcasses were first seen floating on the following dates: 3 September 2002, 6 September 2002, 7 February 2004, 27 June 2010, and 2 March 2012. Coordinates for initial and resighting locations documented drift distances of at least $77 \mathrm{nmi}(143 \mathrm{~km})$ in $22 \mathrm{~d}, 112 \mathrm{nmi}(204 \mathrm{~km})$ in $8 \mathrm{~d}, 54 \mathrm{nmi}(100 \mathrm{~km})$ in $2 \mathrm{~d}, 21 \mathrm{nmi}(39 \mathrm{~km})$ in $3 \mathrm{~d}$, and $27 \mathrm{nmi}(50 \mathrm{~km})$ in $5 \mathrm{~d}$, respectively, giving an average drift distance of $7.3 \mathrm{nmi}(13.5 \mathrm{~km})$ per day or $43.8 \mathrm{nmi}(81.1 \mathrm{~km})$ in $6 \mathrm{~d}$, which we rounded off to $45 \mathrm{nmi}(83.3 \mathrm{~km})$ for mapping convenience. Although these records do not reflect all possible conditions that could influence carcass drift rates, they reflect at least some range of conditions in different seasons and areas and are the best available data at this time.

We conducted a bootstrap resampling analysis (Efron \& Tibshirani 1993) to test the hypothesis that the average annual number of ship-struck whale carcasses found after the speed rule went into effect would be less than the average number during the 18 yr before the speed rule went into effect. This hypothesis was tested separately for right whale carcasses found in or near active SMAs and for right whale carcasses found $>45 \mathrm{nmi}$ from SMAs (Table 1). We did the same for ship-struck humpback whale carcasses. For right whales, annual carcass totals from the 18 yr pre-rule period were resampled one million times, with each sample consisting of a random selection of 5 annual carcass totals to match the number of years in the post-rule period. After each annual total was selected, it was returned to the pool of eligible years so that each draw in a $5 \mathrm{yr}$ sample had 18 annual totals from which to select (i.e. random selection with replacement). We followed the same procedure for humpback whales, but had only $2.5 \mathrm{yr}$ of post-rule data. Therefore, each bootstrap sample for humpback whales consisted of a random selection of 3 annual pre-rule carcass totals. The mean of each bootstrap sample was calculated, and those values were sorted in ascending order. The limits of the upper $95 \%$ of values were used as the confidence interval. The percentage of mean values less than the lower bound constituted the p-value.

To investigate the hypothetical probability of discovering ship-struck right whale carcasses in or near SMAs in the sixth post-rule year, we did an additional bootstrap resampling as described above, but drew 6 values instead of 5 from the pool of 18 prerule annual ship-strike carcass totals in or near SMAs. From those samples we calculated the probability of discovering zero whales in the first $5 \mathrm{yr}$, followed by discovering $\leq 1$ and $\leq 2$ carcasses in the sixth year. We considered only 0,1 , or 2 carcass discoveries because these were the only values observed in any given year during the pre-rule period and, thus, were the only values possible in the bootstrap samples.

We also compared maximum waiting times between discovery of ship-struck right whale and humpback whale carcasses found in or near active SMAs during pre- and post-rule periods to determine the extent to which intervals between recorded ship-collision deaths differed.

\section{RESULTS}

Over the entire study period, 23 of 72 confirmed right whale deaths $(31.9 \%)$ were attributed to ship collisions. Three-fourths of those deaths were in US waters (17 deaths including 15 pre-rule and 2 postrule) and one-fourth (6 deaths) were in Canadian waters (Table 1, Fig. 2). During the 18 yr pre-rule period, 10 of the 15 carcasses in US waters were inside SMAs, and 3 others were within $45 \mathrm{nmi}$ of SMA boundaries (including 2 within just $6 \mathrm{nmi}$ ) during later SMA active dates. Together, those 13 carcasses comprised $87 \%$ of all known ship-strike deaths (Table 2) in US waters during the pre-rule period for an average carcass discovery rate of 0.72 right whales $\mathrm{yr}^{-1}$ in or near active SMAs.

The decomposition state of all ship-struck right whale carcasses found in or near later SMA boundaries in the pre-rule period was moderate or fresher, 
Table 1. Eubalaena glacialis. Date and distance from Seasonal Management Areas (SMAs) of all North Atlantic right whale carcasses attributed to ship collisions along the US East Coast: 1 January 1990 to 8 December 2013, before (pre-rule) and after (post-rule) the SMA implementation on 8 December 2008. Decomposition (Decomp.) codes - 1: alive; 2: fresh; 3: moderate decomposition; 4: advanced decomposition; Unk: unknown condition; nmi: nautical mile

\begin{tabular}{|c|c|c|c|c|c|}
\hline Date (mm/dd/yy) & Nearest SMA & $\begin{array}{c}\text { Inside SMA } \\
\text { dates? }\end{array}$ & $\begin{array}{l}\text { Inside SMA } \\
\text { boundary? }\end{array}$ & $\begin{array}{c}\text { Distance from SMA } \\
(\mathrm{nmi} / \mathrm{km})\end{array}$ & $\begin{array}{l}\text { Decomp. } \\
\text { code }\end{array}$ \\
\hline \multicolumn{6}{|l|}{ Pre-rule } \\
\hline $03 / 12 / 91^{\mathrm{a}}$ & Calving grounds SMA & Yes & Yes & 0 & 3 \\
\hline $01 / 05 / 93^{\mathrm{a}}$ & Calving grounds SMA & Yes & Yes & 0 & 1 \\
\hline $12 / 06 / 93^{a}$ & Chesapeake Bay SMA & Yes & No & $2.6 / 4.8$ & Unk \\
\hline $01 / 30 / 96^{\mathrm{a}}$ & Calving grounds SMA & Yes & Yes & 0 & 3 \\
\hline $03 / 09 / 96^{\mathrm{a}}$ & Cape Cod Bay SMA & Yes & Yes & 0 & Unk \\
\hline $04 / 20 / 99^{a}$ & Cape Cod Bay SMA & Yes & Yes & 0 & 3 \\
\hline $03 / 17 / 01^{\mathrm{a}}$ & Delaware Bay SMA & Yes & No & $36 / 66.7$ & 3 \\
\hline $06 / 18 / 01$ & New York Harbor SMA & No & Yes & 0 & 3 \\
\hline 08/22/02 & Delaware Bay SMA & No & No & $15.4 / 28.5$ & 4 \\
\hline $02 / 07 / 04^{\mathrm{a}}$ & Chesapeake Bay SMA & Yes & Yes & 0 & 3 \\
\hline $11 / 17 / 04^{\mathrm{a}}$ & Chesapeake Bay SMA & Yes & Yes & 0 & 3 \\
\hline $01 / 12 / 05^{\mathrm{a}}$ & Calving grounds SMA & Yes & Yes & 0 & 2 \\
\hline $04 / 28 / 05^{\mathrm{a}}$ & Outer Cape Cod SMA & Yes & No & $5.9 / 10.9$ & 3 \\
\hline $01 / 10 / 06^{a}$ & Calving grounds SMA & Yes & Yes & 0 & 2 \\
\hline $12 / 30 / 06^{\mathrm{a}}$ & Calving grounds SMA & Yes & Yes & 0 & 3 \\
\hline \multicolumn{6}{|l|}{ Post-rule } \\
\hline 07/02/10 & Great South Channel SMA & Yes & No & $112 / 207$ & 3 \\
\hline $03 / 27 / 11$ & Chesapeake Bay SMA & Yes & No & $47 / 86$ & 4 \\
\hline
\end{tabular}

suggesting they may have drifted up to $45 \mathrm{nmi}$ between the time of death and carcass discovery. The 3 longest waiting times between finding such carcasses in the pre-rule period were $2.8 \mathrm{yr}$ (i.e. $1057 \mathrm{~d}$ between 17 March 2001 and 7 February 2004), 2.2 yr (i.e. 785 d between 6 December 1993 and 30 January 1996), and $1.9 \mathrm{yr}$ (i.e. $709 \mathrm{~d}$ between 30 December 2006 and 8 December 2008). Only 2 pre-rule ship strikes were found outside the potential reach of eventual SMA protection provisions; both were inside or within $45 \mathrm{nmi}$ of SMA boundaries, but were discovered $7 \mathrm{wk}$ or more outside later SMA active dates. During the first 5.0 post-rule years, no shipstruck right whales were found in or near any active SMAs, giving a carcass discovery rate of $0 \mathrm{yr}^{-1}$. During that period, 2 ship-struck right whales were found in US waters; both were found within the active dates of the nearest SMA, but were $>45 \mathrm{nmi}$ away from the nearest SMA boundary (one $47 \mathrm{nmi}$ away in Code 4 condition, the other $112 \mathrm{nmi}$ away in Code 3 condition).

Thirty-three right whale deaths were attributed to unknown causes over the entire study period; 29 in US waters and 4 in Canadian. Eight of the 29 in US waters were recovered in moderate to fresh condition (mostly neonates) and were ruled out as possible ship-collision victims based on necropsy results that found no evidence of collision injuries. Therefore, 25 of all mortalities attributed to unknown cause might have been due to ship strikes; 21 in US waters (14 pre-rule and 7 post-rule) and 4 in Canadian waters (Table 3, Fig. 3). During the 18 yr pre-rule period, 8 of the 14 possible ship-strike carcasses in US waters $(57.1 \%)$ were found either inside $(n=5)$ or within $45 \mathrm{nmi}(\mathrm{n}=3)$ of SMA boundaries during their later effective dates for an annual pre-rule discovery rate of 0.44 right whale carcasses $\mathrm{yr}^{-1}$ in or near active SMAs. During the first $5.0 \mathrm{yr}$ after the rule's effective date, 4 of 7 carcasses $(57.1 \%)$ found in US waters attributed to unknown causes that may have included ship strikes were inside $(\mathrm{n}=1)$ or within $45 \mathrm{nmi}$ $(n=3)$ of active SMAs for an average discovery rate of 0.80 carcasses $\mathrm{yr}^{-1}$ (Table 2).

Over the entire study period, 32 humpback whale ship-strike deaths were discovered. They were all in US waters (Table 4, Fig. 4) and included 26 during pre-rule years and 6 during the first 2.5 post-rule years. During the pre-rule period 12 of 26 ship-struck humpback whales $(46 \%)$ were found inside $(n=6)$ or within $45 \mathrm{nmi}(\mathrm{n}=6)$ of SMA boundaries during later SMA effective dates, giving a discovery rate of 0.66 carcasses $\mathrm{yr}^{-1}$ (Table 4). The longest waiting time between finding at least one such carcass in pre-rule years was 5.6 yr (i.e. 2064 d between 14 April 1992 


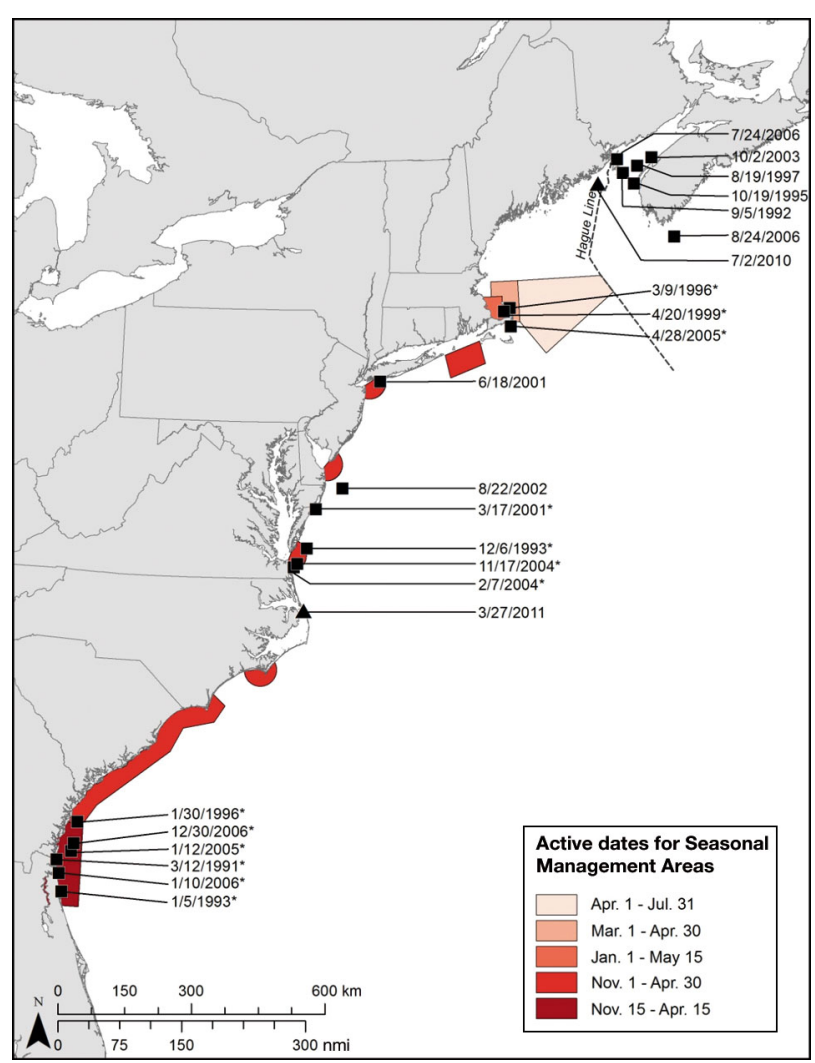

Fig. 2. Eubalaena glacialis. Locations and dates where all North Atlantic right whales killed by ships were found before and after Seasonal Management Areas (SMAs) were established on 8 December 2008. ${ }^{*}$ : carcass found in or within $45 \mathrm{nmi}(83 \mathrm{~km})$ of SMA boundaries during active time frames; $\mathbf{\square}$ : carcass locations during pre-rule years, 1990 to $2008 ; \boldsymbol{\Delta}$ : carcass locations during post-rule years, 9 December 2008 through 8 December 2013

and 10 December 1997), 2.9 yr (i.e. 1090 d between 10 December 1997 and 4 December 2000), and $2.8 \mathrm{yr}$ (i.e. 1045 d between 8 February 2002 and 19 December 2004). During the $2.5 \mathrm{yr}$ (912 d) post-rule period, no ship-struck humpback whales were found inside active SMAs, but 2 were within $45 \mathrm{nmi}$ of active SMAs, giving a post-rule discovery rate of 0.80 humpback whale carcasses $\mathrm{yr}^{-1}$.

From our bootstrap resampling analysis, the upper $95 \%$ confidence interval around the annual pre-rule mean number of right whale ship-strike deaths in or near SMAs (0.72 carcasses $\mathrm{yr}^{-1}$ ) was 0.2 to 2.0 (Fig. 5). As of $5.0 \mathrm{yr}$ after the rule's adoption, the post-rule annual mean number of ship-strike deaths in or near SMAs was 0 . The probability of a 5 yr post-rule carcass discovery rate of 0 is significantly lower $(\mathrm{p}=$ 0.031) than the pre-rule mean. An additional bootstrap resampling analysis was conducted to estimate the probabilities of finding $0, \leq 1$, or $\leq 2$ carcasses in
Table 2. Eubalaena glacialis, Megaptera novaeangliae. Number of known right whale and humpback whale deaths along the US East Coast attributed to ship strikes and unknown causes, possibly including ship strikes, inside or within $45 \mathrm{nmi}$ of active Seasonal Management Area (SMA) boundaries or beyond $45 \mathrm{nmi}$ of SMA boundaries, before and after the SMA implementation on 8 December 2008 (i.e. 8 December 1990 through 8 December 2013 for right whales and through 8 June 2011 for humpback whales)

\begin{tabular}{|lcc|}
\hline & $\begin{array}{c}\text { Pre- } \\
\text { rule }\end{array}$ & $\begin{array}{c}\text { Post- } \\
\text { rule }\end{array}$ \\
\hline Right whales - ship strikes & & \\
Inside or within 45 nmi of SMA boundaries & 13 & 0 \\
Beyond 45 nmi of nearest SMA & 2 & 2 \\
Right whales - unknown cause & & \\
Inside or within 45 nmi of SMA boundaries & 8 & 4 \\
Beyond 45 nmi of nearest SMA & 6 & 3 \\
Humpback whales - ship strikes & & \\
$\begin{array}{l}\text { Inside or within 45 nmi of SMA boundaries } \\
\text { Beyond 45 nmi of nearest SMA }\end{array}$ & 12 & 2 \\
\hline
\end{tabular}

the sixth post-year rule after 5 consecutive years of no deaths. Those probabilities were estimated to be $\mathrm{p}=0.012, \mathrm{p}=0.024$, and $\mathrm{p}=0.031$, respectively.

We found no other significant or borderline significant differences between pre- and post-rule carcass discovery rates. For right whales, there were no apparent differences for (1) ship-struck carcasses found $>45 \mathrm{nmi}$ from active SMAs ( $\mathrm{p}=0.99$ ) or (2) carcasses attributed to unknown causes that might have included ship strikes either in or near active SMAs $(\mathrm{p}=0.92)$ or beyond $45 \mathrm{nmi}$ of the nearest active SMA $(p=0.87)$. For humpback whales, there was no significant difference in discovery rates for ship-struck carcasses either within or near active SMAs $(p=0.68)$ or beyond $45 \mathrm{nmi}$ of the nearest active SMAs $(\mathrm{p}=0.85)$.

\section{DISCUSSION}

\section{Right whales}

Results of this study indicate that the locations and time frames of SMAs were well-chosen to protect North Atlantic right whales from ship strikes. During the $18 \mathrm{yr}$ before SMAs were implemented, 87\% (13 of 15) of all right whales known to have been killed by ships in US waters were found inside or within $45 \mathrm{nmi}$ of SMAs during later SMA effective dates. Indeed, most of those carcasses (i.e. 12 of 15 or $80 \%$ ) were inside or within $6 \mathrm{nmi}$ of SMA boundaries. It therefore appears that most right whales killed by ships before December 2008 were found in or near 
Table 3. Eubalaena glacialis. Date and distance from Seasonal Management Areas (SMAs) of all North Atlantic right whale carcasses attributed to unknown causes, possibly including ship strikes, along the US East Coast: 1 January 1990 to 8 December 2013, before (pre-rule) and after (post-rule) the SMA implementation on 8 December 2008. Decomposition (Decomp.) codes - 1: alive; 2: fresh; 3: moderate decomposition; 4: advanced decomposition; Unk: unknown condition; NC: North Carolina; GA: Georgia

\begin{tabular}{|c|c|c|c|c|c|}
\hline Date (mm/dd/yy) & Nearest SMA & $\begin{array}{l}\text { Inside SMA } \\
\text { dates? }\end{array}$ & $\begin{array}{l}\text { Inside SMA } \\
\text { boundary? }\end{array}$ & $\begin{array}{l}\text { Distance from SMA } \\
(\mathrm{nmi} / \mathrm{km})\end{array}$ & $\begin{array}{l}\text { Decomp. } \\
\text { code }\end{array}$ \\
\hline \multicolumn{6}{|l|}{ Pre-rule } \\
\hline 01/15/93 & Calving grounds SMA & Yes & No & $62 / 115$ & Unk \\
\hline $12 / 06 / 93^{\mathrm{a}}$ & Chesapeake Bay SMA & Yes & No & $1.2 / 2.2$ & Unk \\
\hline $02 / 08 / 96^{\mathrm{a}}$ & Calving grounds SMA & Yes & Yes & 0 & 4 \\
\hline $02 / 19 / 96^{\mathrm{a}}$ & Calving grounds SMA & Yes & Yes & 0 & 3 \\
\hline 10/07/98 & Chesapeake Bay SMA & No & No & $8.5 / 15.7$ & 4 \\
\hline $01 / 19 / 00^{\mathrm{a}}$ & Block Island Sound SMA & Yes & Yes & 0 & Unk \\
\hline $01 / 27 / 01^{\mathrm{a}}$ & Calving grounds SMA & Yes & No & $15 / 28$ & Unk \\
\hline $03 / 17 / 01^{\mathrm{a}}$ & NC-GA Coast SMA & Yes & No & $3 / 5.6$ & 4 \\
\hline $06 / 10 / 02^{\mathrm{a}}$ & Great South Channel SMA & Yes & Yes & 0 & 4 \\
\hline 09/03/02 & Chesapeake Bay SMA & No & No & $38 / 70.3$ & 3 \\
\hline 09/06/02 & Chesapeake Bay SMA & No & No & $65 / 120.3$ & 4 \\
\hline $12 / 09 / 04$ & Great South Channel SMA & No & No & $38 / 70.3$ & Unk \\
\hline 01/09/05 & Great South Channel SMA & No & No & $21 / 38.9$ & 4 \\
\hline $02 / 14 / 08^{\mathrm{a}}$ & Calving grounds SMA & Yes & Yes & 0 & 4 \\
\hline \multicolumn{6}{|l|}{ Post-rule } \\
\hline $02 / 17 / 09^{a}$ & Calving grounds SMA & Yes & Yes & 0 & 3 \\
\hline 02/25/09 & Great South Channel SMA & No & Yes & 0 & 3 \\
\hline 08/18/09 & New York Harbor SMA & No & No & $44 / 81.5$ & 4 \\
\hline $12 / 19 / 09$ & Great South Channel SMA & No & No & $6.1 / 11.3$ & 2 \\
\hline $02 / 19 / 11^{\mathrm{a}}$ & NC-GA SMA & Yes & No & $34 / 63.0$ & 4 \\
\hline $03 / 17 / 11^{\mathrm{a}}$ & Delaware Bay SMA & Yes & No & $40 / 74.1$ & 3 \\
\hline $03 / 02 / 12^{\mathrm{a}}$ & Race Point SMA & Yes & No & $24 / 44.5$ & 3 \\
\hline
\end{tabular}

areas where SMAs were later established and also during their eventual effective dates.

The results also suggest that SMAs have effectively reduced the number of whale deaths due to ships. Average annual discovery rates of ship-struck right whale carcasses in or near active SMAs declined significantly from 0.72 to 0 carcasses $\mathrm{yr}^{-1}$ for at least the first $5.0 \mathrm{yr}$ after the rule went into effect. This measure of reduction is likely to be conservative given that estimates of the size of the North Atlantic right whale population increased over the study period from about 295 whales in 1992 (Knowlton et al. 1994) to about 500 whales in 2013, with the addition of about 80 whales from 2008 through 2013 (New England Aquarium unpubl. data). Thus, the number of whales available to be struck has increased in postrule years. In addition, the $5.0 \mathrm{yr}$ post-rule period during which no ship-struck right whales carcass were discovered in or near any acitve SMAs is almost twice as long as the longest gap (i.e. 2.8 yr) between such discoveries during the pre-rule period.

These results are encouraging, but require a longer time period to confirm if the apparent effec- tiveness holds up over time. The recommended routing changes off Boston, the new recommended routes in Cape Cod Bay and the southeastern US calving grounds, and new ATBA also may have contributed to the apparent reduction in right whale ship-strike deaths by directing traffic through habitats used somewhat less frequently by whales. For example, a $58 \%$ reduction in collision risks was predicted by shifting a segment of the Boston shipping lanes (www.scimaps.org/maps/ map/realigning_the_bosto_88/), and Fonnesbeck et al. (2008) predicted as much as a $44 \%$ reduction with new shipping lanes through the calving grounds. However, the new routes must still cross key right whale habitats, and no useful routing alternatives exist for mid-Atlantic ports along the right whale's coastal migratory corridor, where nearly half of all vessel-related right whale deaths have been discovered. Thus, although there should be some uncertain amount of risk reduction from new routes now in place, we believe speed restrictions are likely to be a more important factor in reducing collision risks along the US East Coast. 


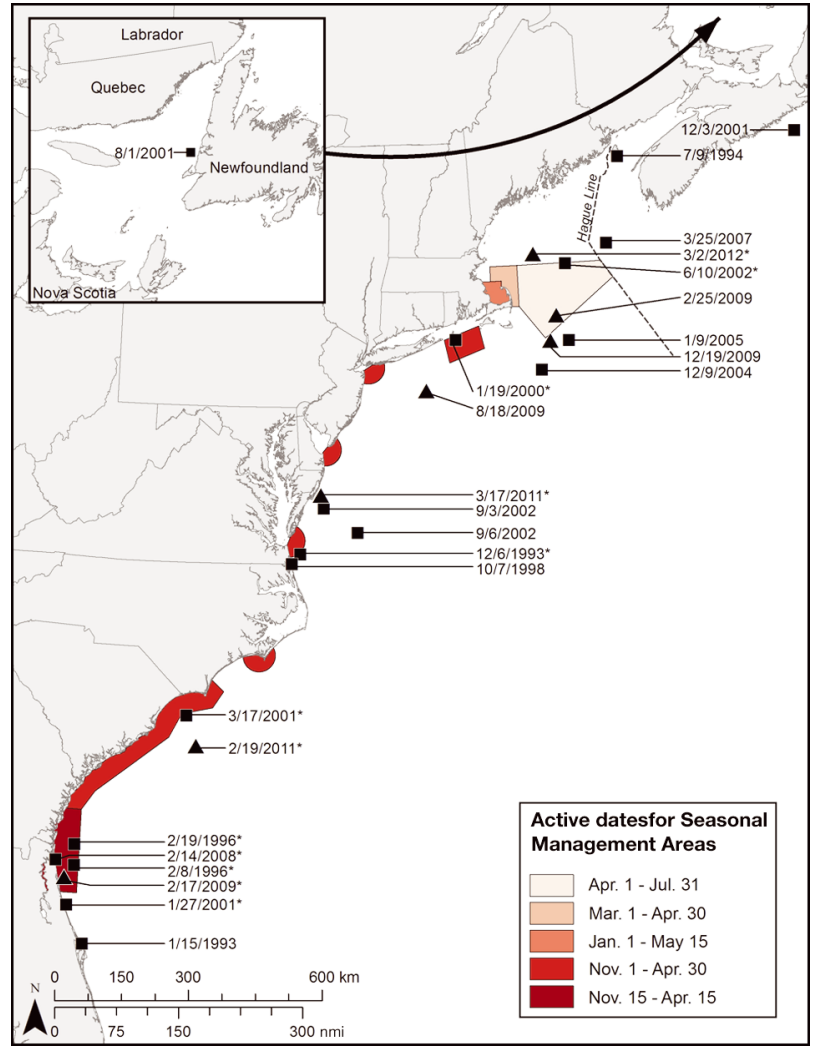

Fig. 3. Eubalaena glacialis. Locations and dates where all North Atlantic right whales killed by unknown causes, possibly including ship strikes, were found before and after Seasonal Management Areas (SMAs) were established on 8 December 2008. ${ }^{*}$ : carcass found in or within $45 \mathrm{nmi}(83 \mathrm{~km})$ of SMA boundaries during active time frames; $\mathbf{\square}$ : carcass locations during pre-rule years, 1990 to 2008; $\boldsymbol{\Delta}$ : carcass locations during post-rule years, 9 December 2008 through 8 December 2013

We found no indication that SMAs have reduced the number of right whale deaths attributed to unknown causes. The percentages of such deaths in or near active SMAs in the pre-rule $(57.1 \%, 8$ of 14$)$ and post-rule $(57.1 \%, 4$ of 7$)$ periods were identical, and the average annual carcass recovery rate actually increased from 0.44 to 0.80 carcasses $\mathrm{yr}^{-1}$ during the post-rule period. The most parsimonious interpretations for the increase in deaths due to unknown causes are that (1) all or most right whale deaths that may have been attributed to unknown causes but were actually due to ship strikes occurred $>45 \mathrm{nmi}$ from the nearest active SMA, (2) most right whale deaths attributed to unknown causes were not caused by ship collisions, and the increase reflects stochastic variability. As indicated below, an example of the first possibility may be the cluster of 4 carcasses attributed to unknown causes found in the southern Great South Channel area in winter. This is an area with high ship traffic and limited winter survey effort. The second possibility has some support from past experience. During a 4 yr period between 1993 and 1996, the annual discovery rate for right whale carcasses attributed to unknown causes in or near later active SMAs was 0.75 carcasses $\mathrm{yr}^{-1}$ ( 3 of 4 carcasses), which approaches the post-rule rate of 0.80 (Table 3).

Other studies have found little or no evidence that recent management measures have reduced vesselrelated right whale deaths along the US East Coast. Analyses to date, however, have been too broad in scope, or involved time frames ill-suited for assessing effectiveness of the SMA network. For example, van der Hoop et al. (2013) found no noticeable reduction in large whale vessel- and entanglement-related deaths from 2003 through 2009 (when a number of management actions were implemented, including outreach efforts to advise mariners of collision risks), compared to earlier years. That study, however, was not designed to assess the effectiveness of site-specific measures or specifically of SMA vessel-speed restrictions. In particular, it included only 1 yr of data after SMAs were established.

Similarly, Pace (2011) found no significant reduction in ship-collision deaths after the rule went into effect. However, his analysis was based on only $2 \mathrm{yr}$ of post-rule data, measured intervals between collisions involving all species of large whales (i.e. humpback, right, fin, and sei whales), considered all types of vessels (including those $<65 \mathrm{ft}$ in length that are not subject to regulation), and included all US and Canadian waters (including those not near SMAs). Furthermore, it did not distinguish between collisions inside versus outside SMA time frames. In contrast, our analysis focuses on those collisions most likely to have occurred within SMA boundaries, during effective dates, on the species of greatest concern (i.e. right whales), and on the vessels most likely to have been subject to management (i.e. all carcasses considered in this analysis had large wounds or contusions indicative of collisions with vessels that likely were $>65$ feet long). Therefore, we believe this analysis provides a more direct and useful measure of the rule's effectiveness for right whales.

\section{Humpback whales}

Our results suggest that SMAs have not provided a significant benefit for humpback whales. Whereas $87 \%$ of all ship-struck right whales were found in or near SMAs during effective dates in the pre-rule period, less than half $(46 \%)$ of all such humpback 
Table 4. Megaptera novaeangliae. Date and distance from Seasonal Management Areas (SMAs) of all humpback whale carcasses attributed to ship strikes along the US East Coast: 1 January 1990 to 8 June 2011, before (pre-rule) and after (post-rule) the SMA implementation on 8 December 2008. Decomposition (Decomp.) codes - 1: alive; 2: fresh; 3: moderate decomposition; 4: advanced decomposition; Unk: unknown condition; NC: North Carolina; GA: Georgia

\begin{tabular}{|c|c|c|c|c|c|}
\hline Date (mm/dd/yy) & Nearest SMA & $\begin{array}{l}\text { Inside SMA } \\
\text { dates? }\end{array}$ & $\begin{array}{l}\text { Inside SMA } \\
\text { boundary? }\end{array}$ & $\begin{array}{c}\text { Distance from SMA } \\
(\mathrm{nmi} / \mathrm{km})\end{array}$ & $\begin{array}{l}\text { Decomp. } \\
\text { code }\end{array}$ \\
\hline \multicolumn{6}{|l|}{ Pre-rule } \\
\hline $11 / 08 / 91^{\mathrm{a}}$ & New York Harbor SMA & Yes & No & $22.6 / 41.9$ & Unk \\
\hline $02 / 14 / 92^{\mathrm{a}}$ & Chesapeake Bay SMA & Yes & Yes & 0 & 3 \\
\hline $04 / 16 / 92^{\mathrm{a}}$ & Delaware Bay SMA & Yes & No & $22.7 / 42.0$ & 4 \\
\hline 06/04/95 & Chesapeake Bay SMA & No & No & $0.1 / 0.2$ & 3 \\
\hline 05/09/96 & Delaware Bay SMA & No & No & $0.5 / 0.9$ & 3 \\
\hline $11 / 03 / 96^{\mathrm{a}}$ & Chesapeake Bay SMA & Yes & No & $42.9 / 79.5$ & 3 \\
\hline $12 / 10 / 97^{a}$ & Morehead City SMA & Yes & Yes & 0 & 3 \\
\hline $12 / 04 / 00^{\mathrm{a}}$ & Morehead City SMA & Yes & Yes & 0 & \\
\hline 01/25/01 & Chesapeake Bay SMA & Yes & No & $51.6 / 95.6$ & 2 \\
\hline $04 / 08 / 01^{\mathrm{a}}$ & NC-GA Coast SMA & Yes & Yes & 0 & 2 \\
\hline 07/29/01 & New York Harbor SMA & No & No & $6.8 / 12.6$ & 3 \\
\hline 08/18/01 & Delaware Bay SMA & No & No & $22.5 / 41.7$ & 2 \\
\hline 10/01/01 & Cape Cod Bay SMA & No & Yes & 0 & 3 \\
\hline $02 / 08 / 02^{\mathrm{a}}$ & Chesapeake Bay SMA & Yes & No & $4.8 / 8.9$ & Unk \\
\hline 05/30/02 & Race Point SMA & No & No & $51.7 / 95.7$ & 3 \\
\hline 08/01/02 & New York Harbor SMA & No & No & 0 & 4 \\
\hline 06/06/03 & Chesapeake Bay SMA & No & No & $4.6 / 8.5$ & $2-3$ \\
\hline $12 / 19 / 04^{\mathrm{a}}$ & Delaware Bay SMA & Yes & Yes & 0 & 3 \\
\hline $01 / 09 / 06^{\mathrm{a}}$ & NC-GA Coast SMA & Yes & Yes & 0 & 3 \\
\hline $03 / 17 / 06^{\mathrm{a}}$ & Chesapeake Bay SMA & Yes & No & $1.5 / 2.8$ & 3 \\
\hline 09/27/06 & Delaware Bay SMA & No & Yes & 0 & 4 \\
\hline 10/15/06 & Delaware Bay SMA & No & No & $6.2 / 11.5$ & 4 \\
\hline 05/10/07 & Chesapeake Bay SMA & No & No & $21.6 / 40.0$ & 4 \\
\hline 05/13/07 & Race Point SMA & No & No & $9.2 / 17.0$ & 4 \\
\hline 06/24/07 & Race Point SMA & No & Yes & 0 & 3 \\
\hline $11 / 04 / 08^{\mathrm{a}}$ & Delaware Bay SMA & Yes & No & $20.1 / 37.2$ & 2 \\
\hline \multicolumn{6}{|l|}{ Post-rule } \\
\hline 07/27/09 & New York Harbor SMA & No & Yes & 0 & 3 \\
\hline $03 / 13 / 10^{\mathrm{a}}$ & Delaware Bay SMA & Yes & No & $12.8 / 23.7$ & 3 \\
\hline 06/10/10 & New York Harbor SMA & No & No & $0.1 / 0.2$ & 3 \\
\hline 07/04/10 & Delaware Bay SMA & No & No & $12.0 / 22.2$ & 4 \\
\hline $03 / 07 / 11^{\mathrm{a}}$ & Morehead City SMA & Yes & No & $15 / 27.8$ & 1 \\
\hline 05/28/11 & New York Harbor & No & No & $23.9 / 44.3$ & 4 \\
\hline
\end{tabular}

whales were in or near those areas during active dates. However, it is notable that 12 of the other 15 pre-rule humpback whales killed by ships were found in or near SMA boundaries, but were outside of SMA active dates (Table 5). This pattern persisted in post-rule years when all 6 of the ship-struck humpback whale carcasses were found in or near SMA boundaries, but only 2 were within their active dates. Thus, it would seem that SMAs could be beneficial for humpback whales if their effective dates were expanded to better reflect the timing of their seasonal occurrence in SMA boundaries. The occurrence of humpback whale collisions outside of active dates is understandable given that SMA time frames were developed specifically for right whale protection.

\section{Uncertainties in the time and location of collisions}

In addition to constraints due to the small sample size of ship-struck carcasses on the statistical power of our analyses, 2 other limitations led to uncertainties: (1) the precise dates of collisions and (2) the precise locations of collisions relative to SMA dates and boundaries. Because the length of time between a collision and the discovery of collision-related carcasses is unknown and variable, there is some uncertainty about whether those whales were struck during SMA active dates. In most cases, we believe carcass discovery dates can be related with reasonable accuracy to active SMA dates. All ship-struck right whale carcasses found in or near SMAs during 


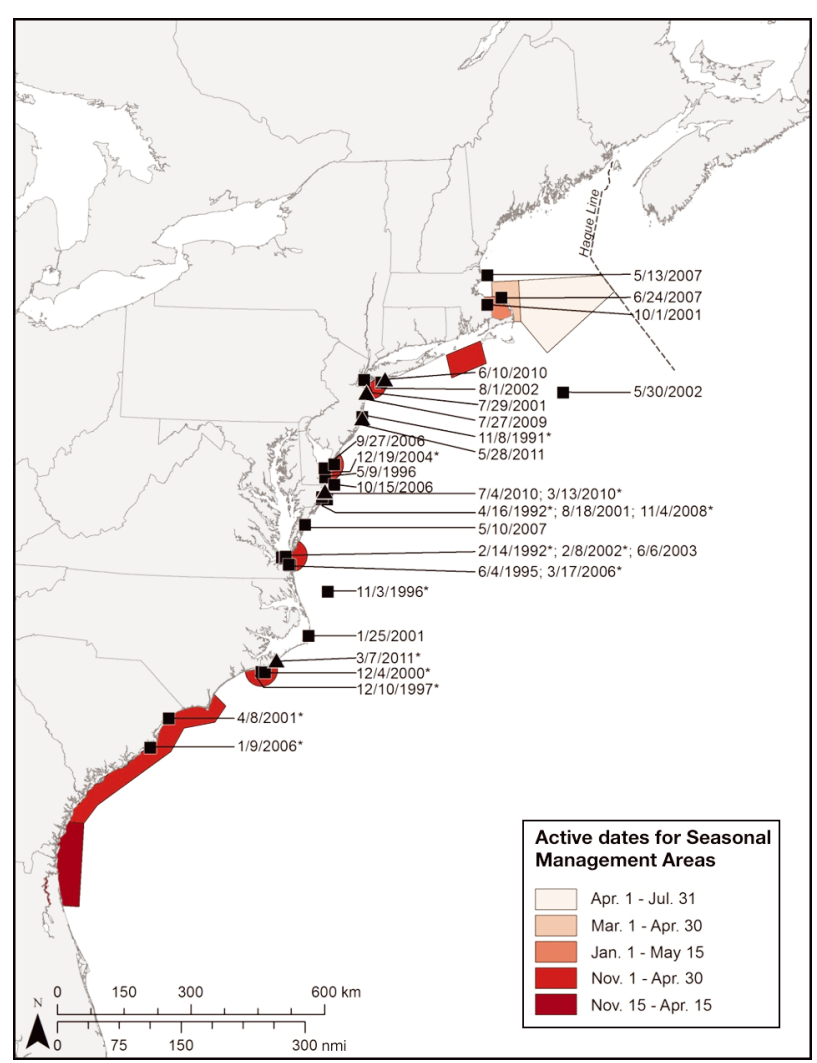

Fig. 4. Megaptera novaeangliae. Locations and dates where all humpback whales killed by ships were found before and after Seasonal Management Areas (SMAs) were established on 8 December 2008. *: carcass found in or within $45 \mathrm{nmi}$ $(83 \mathrm{~km})$ of SMA boundaries during active time frames; carcass locations during pre-rule years, 1990 to 2008 ; $\boldsymbol{\Delta}$ : carcass locations during post-rule years, 9 December 2008 through 8 June 2013

pre-rule years with information on their decomposition state (i.e. 11 of 13) were moderately decomposed (Code 3) or fresher. Similarly, all but 1 ship-struck humpback whale found in or near SMAs with information on decomposition condition ( 7 of 8) were Code 3 or fresher. As noted above, right whale carcasses can degrade to a Code 3 condition within a week or less. Because most right whale carcasses attributed to ship strikes along the US East Coast have involved massive injuries, such as fractured skulls or vertebrae, severed tail stocks, and long, deep propeller wounds (Moore et al. 2004), it seems reasonable to assume that most victims die within a day or 2, if not hours, of being hit. By adding those pre- and post-mortem times together, it seems likely that most ship-collision deaths reported in this study occurred no more than about 7 to $8 \mathrm{~d}$ before the discovery dates. Only 1 ship-struck whale found in or near an SMA was found $<9 \mathrm{~d}$ after the beginning or

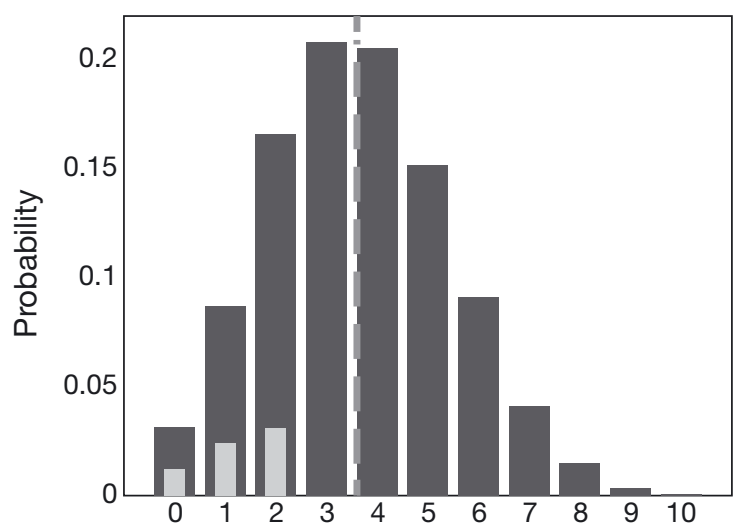

Number of right whale carcasses found in or near SMAs

Fig. 5. Eubalaena glacialis. Probabilities of finding 0 to 10 right whale carcasses in or near Seasonal Management Areas (SMAs) over the $5 \mathrm{yr}$ post-rule period (8 December 2008 to 8 December 2013) based on bootstrap resampling of discovery records during the 18 yr pre-rule period (8 December 1990 to 7 December 2008). Dark gray bars show probabilities of 5 yr totals assuming whales could be found in any year during the $5 \mathrm{yr}$ period; light gray bars show probabilities assuming no whales were found in years 1 to 5 and $0, \leq 1$, or $\leq 2$ whales were found in Year 6; gray dashed line shows the annual mean pre-rule discovery rate of 0.72 (equivalent to 3.6 carcasses over $5 \mathrm{yr}$ )

end dates of the nearest active SMA (i.e. a humpback whale with no information on its decomposition state was found $8 \mathrm{~d}$ after the start of the nearest SMA $22.6 \mathrm{nmi}$ away). Thus, it seems reasonable to believe that most, if not all, carcasses considered to have been struck in or near SMAs during active SMA dates were in fact struck during those periods.

Far less clear is whether ship-strike victims found in or near SMA boundaries were in fact struck within SMA boundaries. Complicating factors include the possibility of whales swimming some distance after being struck and before they die and drift an additional distance from collision locations. Because of those possibilities, some dead whales discovered outside SMA boundaries may have been struck inside SMA boundaries and vice versa. In general, it seems unlikely that lethally struck whales would swim long distances after being hit. Even if whales do not die instantly or within a few hours, massive injuries typical of collision deaths are likely to leave them moribund or highly immobile. Transport of moribund or dead whales by wind and currents is more difficult to gauge. As noted above, resighted right whale carcasses drifted an average of $7 \mathrm{nmi} \mathrm{d}^{-1}$, and 1 drifted $112 \mathrm{nmi}(204 \mathrm{~km})$ in $8 \mathrm{~d}$, for an average of $14 \mathrm{nmi}$ $(26 \mathrm{~km}) \mathrm{d}^{-1}$. Thus, it is possible that some ship-struck carcasses could have drifted into SMAs from adja- 
cent areas. Indeed, given that 5 of 8 right whale carcasses found inside SMA boundaries during pre-rule years were moderately decomposed, it would seem likely that at least some drifted $45 \mathrm{nmi}$ before being found, which could have put them outside but near SMA boundaries.

A detailed analysis of carcass drift for ship-strike victims found in the past was beyond the scope of this study. To improve understanding of where shipstrike victims are actually struck relative to SMA boundaries in the future, we recommend conducting a retrospective drift analysis as a routine part of investigations for future ship-struck right whale carcasses. Where possible, estimates should be made during necropsies of the time between death and the discovery of all carcasses attributed to ship strikes. That time span should then be used to trace the possible drift path back to a predicted location at the time of death based on prevailing winds and currents over that period.

Despite uncertainty about precisely where past ship-strike victims were struck, the pattern of carcass recovery shown in Fig. 2 strongly suggests that nearly $90 \%$ of all right whale deaths attributed to ship strikes in US waters since 8 December 1990 and before the rule became effective were struck in or near SMAs during the periods in which these were in effect. The possibility that some of those whales were struck in waters adjacent to SMA boundaries underscores the importance of expanding SMA boundaries along the species' migratory corridor (i.e. from Georgia to New York) to the $30 \mathrm{nmi}$ limit originally proposed by the NMFS based on its past assessment of the width of the right whale migratory corridor and relevant new information. In addition, we recommend that further studies be undertaken to better define the distances from shore that most right whales travel during their migrations in spring and fall between Georgia and New York.

\section{SMA boundaries}

With half of all known right whale deaths in US waters since 1990 due to ship strikes found along the species' migratory corridor-which is thought to extend to approximately $30 \mathrm{nmi}$ from shore (Schick 2009, Keller et al. 2012) - failure to include waters between 20 and $30 \mathrm{nmi}$ in SMA boundaries leaves a potentially significant gap in protection of right whales from ship collisions. Its lack of inclusion also complicates evaluations of SMA effectiveness. With current SMA boundaries along the migratory corri- dor set as $20 \mathrm{nmi}$ arcs around port entrances, it is possible that vessels entering or leaving port may hit whales in the offshore third of the species' presumed migratory corridor (i.e. 20 to $30 \mathrm{nmi}$ from shore), where speed limits do not apply. Those carcasses may drift into SMAs and be assumed incorrectly to have been struck by ships complying with speed restrictions inside an SMA. Also, because carcass detection and retrieval becomes more difficult as distance from shore increases, whales struck and killed in this offshore zone that do not drift towards shore may be underestimated.

To more rigorously protect right whales and reduce uncertainty about whether ship-strike victims are struck just beyond SMA boundaries where speed restrictions do not apply, we recommend that (1) the boundaries of the SMAs along the species' migratory corridor be extended to $30 \mathrm{nmi}$ from shore, as initially proposed by the NMFS; (2) the configuration of SMAs be modified from an arc to a rectangle, with boundaries extending perpendicular from the points where current SMA perimeters intersect with land out to $30 \mathrm{nmi}$ offshore, to cover a greater portion of vessel tracks across core migratory areas; and (3) SMAs be made effective indefinitely, with a view towards retaining them unless further analyses demonstrate they are ineffective or should be modified. Changing SMA boundaries along the migratory corridor from arcs to rectangles that extend 20 (or 30) nmi from shore would increase their size by about $25 \%$. This change would increase the probability that ships entering or leaving port along routes that are not perpendicular to the coast would travel at speeds safe for whales when transiting areas where migrating whales are most likely to be encountered.

It is also interesting that several right whale deaths due to unknown causes, possibly including ship strikes, were found offshore at distances and/or at times of the year when retrieval was more difficult. In this regard, 4 of 15 right whale deaths of unknown cause were clustered in or near the southern tip of the Great South Channel SMA from December through February, when that SMA was not in effect (Fig. 2). Those deaths, which occurred at a time of year with poor weather conditions and where carcass retrieval is very difficult, lie near an area where several heavily used vessel traffic corridors intersect (Ward-Geiger et al. 2005). That area may, therefore, be an additional site where ship collision risks are high and where the designation of an SMA should be considered. In general, carcasses are less likely to be found farther offshore, because of reduced survey effort. We do not, however, believe this bias would 
alter our conclusions, because, with the exception of waters in the Gulf of Maine, right whale occurrence is believed to decrease in waters beyond $30 \mathrm{nmi}$ from shore. In addition, those areas were not subject to regulation either before or after the rules went into effect, and thus right whale occurrence in or near SMAs should not differ in either period. The whales' distance from shore may also make it less likely they would drift into SMAs.

\section{CONCLUSIONS}

Analyses of the locations where ship-struck whale carcasses are found provide useful methods for evaluating the biological effectiveness of SMAs established to protect North Atlantic right whales. The overall pattern of carcass discovery locations shown in Fig. 2 strongly suggests that a large majority of ship-collision victims found in pre-rule years were struck by ships entering and leaving ports where the 10 SMAs were later designated and also on dates that coincided with periods in which the later SMAs were in effect. The increased waiting time between discovery of ship collisions in or near active SMAs after the December 2008 implementation (i.e. $5.0 \mathrm{yr}$ as of the date of this analysis) also suggests that the seasonal 10 knot speed limit has been effective, although additional time is needed to confirm longterm trends. When the rule was adopted, it was thought it would also benefit humpback whales, but there is no evidence from this analysis that this has been true. Numerous collisions involving humpback whales were found within or near SMA boundaries, but most were not during active SMA dates.

Based on these results, speed restrictions and the existing SMAs are tools that should be kept in place indefinitely. Dredged channels passing through SMAs should not be exempted from restrictions, as requested by petition, because whales must travel across those channels and are at no less risk of being struck in those channels. The rules appear to have been effective and remain necessary to prevent shiprelated right whale deaths. However, to better cover areas where right whales are at greatest risk, SMA boundaries along the right whale migratory corridor should be extended from 20 to $30 \mathrm{nmi}$ from shore, as originally proposed by the NMFS. In addition, consideration should be given to: (1) changing the configuration of SMA boundaries off ports in mid-Atlantic states from arcs to rectangles, to better protect whales migrating farther offshore; (2) establishing a new winter SMA along a segment of desig- nated shipping lanes south of the Great South Channel SMA, where 4 unretrieved right whale carcasses possibly struck by ships were found in the months of December through February; and (3) extending the dates of SMAs, to better cover times when humpback whales are likely to occur in SMA boundaries. Given the apparent effectiveness of reduced speed limits and experience indicating a lack of compliance with voluntary requests to use reduced speeds (McKenna et al. 2012, Silber et al. 2012b), we also recommend that speed limits in short-term DMA zones be made mandatory, rather than voluntary, to protect periodic right whale aggregations found outside of active SMAs. Our study provides encouraging evidence that 10 knot speed restrictions are effective for reducing vessel-related right whale deaths. Such restrictions should be considered as an option for mitigating vessel strikes of large whales in other parts of the world where this problem is considered significant.

Acknowledgements. We thank Mendy Garron and Allison Henry of the National Marine Fisheries Service for searching the National Marine Mammal Strandings database. We also thank Brooke Wikgren of the New England Aquarium for plotting those records on a study area map, calculating distances of carcasses from SMA boundaries, and preparing the figures in this paper. Peter Thomas, Michael Tlusty, and 4 anonymous reviewers also provided constructive comments on various drafts for which we are very grateful. We also acknowledge and thank all the necropsy team leaders and stranding program participants whose hard work was essential in creating this valuable database.

\section{LITERATURE CITED}

Asaro MJ (2012) Geospatial analysis of management areas implemented for protection of the North Atlantic right whale along the northern Atlantic coast of the United States. Mar Policy 36:915-921

Clyne H (1999) Computer simulations of interactions between the North Atlantic right whale (Eubalaena glacialis) and shipping. Masters thesis in Software Technology, Napier University, Edinburgh

Conn PB, Silber GK (2013) Vessel speed restrictions reduce risk of collision-related mortality for North Atlantic right whales. Ecosphere 4(4):Article 43

Efron B, Tibshirani RJ (1993) An introduction to the bootstrap. Chapman \& Hall, New York, NY

Fonnesbeck CJ, Garrison LP, Ward-Geiger LI, Baumstark RD (2008) Bayesian hierarchical model for evaluating the risk of vessel strikes on North Atlantic right whales in the SE United States. Endang Species Res 6:87-94

Gende SM, Hendrix AN, Harris KR, Eichenlaub B, Nielson J, Pyare S (2011) A Bayesian approach for understanding the role of ship speed in whale-ship encounters. Ecol Appl 21:2232-2240

Geraci JR, Lounsbury VJ (2005) Marine mammals ashore: a field guide for strandings, 2nd edn. National Aquarium in Baltimore, Baltimore, MD 
Keller CA, Garrison L, Baumstark R, Ward-Geiger LI, Hines E (2012) Application of a habitat model to define calving habitat of the North Atlantic right whale in the southeastern United States. Endang Species Res 18:73-87

Knowlton AR, Kraus SD (2001) Mortality and serious injury of northern right whales (Eubalaena glacialis) in the western North Atlantic Ocean. J Cetacean Res Manag 2(Spec Issue):193-208

Knowlton AR, Kraus SD, Kenney RD (1994) Reproduction in North Atlantic right whales (Eubalaena glacialis). Can J Zool 1297-1305

Knowlton AR, Korsmeyer FT, Kerwin JE, Wu HY, Haynes B (1995) The hydrodynamic effects of large vessels on right whales. Contract No. 40ANFF400534, final report to the National Marine Fisheries Service, Northeast Fisheries Science Center, Woods Hole, MA

Knowlton AR, Hamilton PK, Marx MK, Pettis HM, Kraus SD (2012) Monitoring North Atlantic right whale Eubalaena glacialis entanglement rates: a $30 \mathrm{yr}$ retrospective. Mar Ecol Prog Ser 466:293-302

Kraus SD, Brown MW, Caswell H, Clark CW and others (2005) North Atlantic right whales in crisis. Science 309: 561-562

Lagueux KM, Zani MA, Knowlton AR, Kraus SD (2011) Response by vessel operators to protection measures for right whales Eubalaena glacialis in the southeast US calving ground. Endang Species Res 14:69-77

Laist DW, Knowlton AR, Mead JG, Collet AS, Podesta M (2001) Collisions between ships and whales. Mar Mamm Sci 17:35-75

Marine Mammal Commission (2008) The biological viability of the most endangered marine mammals and the costeffectiveness of protection programs: a report to Congress from the Marine Mammal Commission. Available at http://mmc.gov/reports/publications/welcome.shtml (accessed 26 February 2013)

Marine Mammal Commission (2013) Annual Report to Congress 2010-2011 Marine Mammal Commission. Available at http://mmc.gov/reports/annual/welcome. shtml (accessed 1 Jannuary 2014)

McKenna MF, Katz SL, Condit C, Walbridge S (2012) Response of commercial ships to a voluntary speed reduction measure: Are voluntary strategies adequate for mitigating ship-strike risk? Coast Manage 40:634-650

Moore MJ, Knowlton AR, Kraus SD, McLellan WA, Bonde RK (2004) Morphometry, gross morphology and available histopathology in North Atlantic right whale (Eubalaena glacialis) mortalities (1970-2002). J Cetacean Res Manag 6:199-214

Mueller M, Ortega-Ortiz JG, Zoodsma B (2011) Vessel compliance with right whale protection measures in the southeast U.S. seasonal management area: trends from 5 years of monitoring. In: Abstracts of the 19th Biennial Conf Biol Marine Mammals. Society for Marine Mammalogy, Lawrence, KS, p 213

National Marine Fisheries Service (2005) Recovery plan for the North Atlantic right whale Eubalaena glacialis revision. U.S. Department of Commerce, National Oceanic and Atmospheric Administration, Office of Protected Species, Silver Spring,MD. Available at www. nmfs.noaa.gov/pr/recovery/plans.htm (accessed 10 October 2013)

National Marine Fisheries Service (2006) Proposed rule to implement speed restrictions to reduce the threat of ship collisions with North Atlantic right whales. Fed Regist
71:36299-36313. Available at www.nmfs.noaa.gov/pr/ pdfs/fr/fr71-36299.pdf (accessed 26 February 2013)

National Marine Fisheries Service (2008a) Final rule to implement speed restrictions to reduce the threat of ship collisions with North Atlantic right whales. Fed Regist 73:60173-60191. Available at www.nmfs.noaa.gov/pr/ pdfs/fr/fr73-60173.pdf (accessed 10 October 2013)

National Marine Fisheries Service (2008b) Final environmental impact statement to implement the operational measures of the North Atlantic right whale shipstrike reduction strategy. Office of Protected Species, National Marine Fisheries Service, Silver Spring, MD. Available at www.nmfs.noaa.gov/pr/pdfs/shipstrike/feis. pdf (accessed 10 October 2013)

National Marine Fisheries Service (2013) Final rule to eliminate the sunset provision of the final rule implementing vessel speed restrictions to reduce the threat of ship collisions with North Atlantic right whales. Fed Regist 78: 73726-73736. Available at www.gpo.gov/fdsys/pkg/FR2013-12-09/pdf/2013-29355.pdf (accessed 20 December 2013)

Pace RM III (2011) Frequency of whale and vessel collisions on the US eastern seaboard: ten years prior and two years post ship-strike rule. NOAA/NEFSC Reference Document 11-15, Woods Hole, MA. Available at http:// nefsc.noaa.gov/publications/crd/crd1115/ (accessed 26 February 2013)

Reeves RR, Smith TD, Josephson EA (2007) Near-annihilation of a species: right whaling in the North Atlantic. In: Kraus SD, Rolland RM (eds) The urban whale: North Atlantic right whales at the crossroads. Harvard University Press, Cambridge, MA p 39-74

Russell BA, Knowlton AR, Zoodsma B (2001) Recommended measures to reduce ship strikes of North Atlantic right whales. Report submitted to the National Marine Fisheries Service in partial fulfillment of NMFS Contract 40EMF9000223. National Marine Fisheries Service, Office of Protected Resources, Silver Spring, MD. Available at www.nero.noaa.gov/shipstrike/subinfo/finalreport.pdf (accessed 26 February 2013)

Schick RS (2009) Striking the right balance in right whale conservation. Can J Fish Aquat Sci 66:1399-1403

Silber GK, Bettridge S (2009) Report of a workshop on assessing the effectiveness of the right whale ship-strike reduction rule. NOAA Tech Memo NMFS-OPR-42, Office of Protected Resources, National Marine Fisheries Service, Silver Spring, MD. Available at www.nmfs. noaa.gov/pr/pdfs/shipstrike/technology_workshop report.pdf (accessed 26 February 2013)

Silber GK, Bettridge S (2010) Vessel operations in right whale protection areas in 2009. U.S. Department of Commerce, NOAA Tech Memo NMFS-OPR-44, Office of Protected Resources, National Marine Fisheries Service, Silver Spring, MD. Available at www.nmfs.noaa.gov/pr/ pdfs/shipstrike/opr44.pdf (accessed 26 February 2013)

Silber GK, Bettridge S (2012) An assessment of the final rule to implement vessel speed restrictions to reduce the threat of vessel collisions with North Atlantic right whales. NOAA Tech Memo NMFS-OPR-48, Office of Protected Resources, National Marine Fisheries Service, Silver Spring, MD. Available at www.nmfs.noaa.gov/ pr/pdfs/shipstrike/assessment_nmfsopr48.pdf (accessed 26 February 2013)

Silber GK, Slutsky J, Bettridge S (2010) Hydrodynamics of a ship/whale collision. J Exp Mar Biol Ecol 391:10-19 
Silber GK, Vanderlaan ASM, Arceredillo AJ, Johnson L and others (2012a) The role of the International Maritime Organization in reducing vessel threat to whales: process, options, action and effectiveness. Mar Policy 36:1221-1233

Silber GK, Adams JD, Bettridge S (2012b) Vessel operator response to a voluntary measure for reducing collisions with whales. Endang Species Res 17:245-254

van der Hoop JM, Moore MJ, Barco SG, Cole TVN and others (2013) Assessment of management to mitigate anthropogenic effects on large whales. Conserv Biol 27: 121-133

> Vanderlaan ASM, Taggart CT (2007) Vessel collisions with whales: the probability of lethal injury based on vessel speed. Mar Mamm Sci 23:144-156

> Vanderlaan ASM, Taggart CT, Serdynska AR, Kenney RD,

Editorial responsibility: Simon Goldsworthy, West Beach, Australia
Brown MW (2008) Reducing the risk of lethal encounters: vessels and right whales in the Bay of Fundy and on the Scotian Shelf. Endang Species Res 4:283-297

Vanderlaan ASM, Corbett JJ, Green SL, Callahan JA and others (2009) Probability and mitigation of vessel encounters with North Atlantic right whales. Endang Species Res 6:273-285

Ward-Geiger LI, Silber GK, Baumstark RD, Pulfer TF (2005) Characterization of ship traffic in right whale critical habitat. Coast Manage 33:263-278

Wiley DN, Thompson M, Pace RM III, Levenson J (2011) Modeling speed restrictions to mitigate lethal collisions between ships and whales in the Stellwagen Bank National Marine Sanctuary, USA. Biol Conserv 144: 2377-2381

Submitted: December 4, 2012; Accepted: January 23, 2014 Proofs received from author(s): February 21, 2014 